\title{
Final \\ Environmental Assessment for the Space Complex-5 SCOUT Launcher Relocation \\ Vandenberg Air Force Base, California
}

Prepared By:

30th Civil Engineer Squadron

Environmental Flight

Vandenberg AFB

CA 93437

January, 2009 


\section{Report Documentation Page}

Form Approved

OMB No. 0704-0188

Public reporting burden for the collection of information is estimated to average 1 hour per response, including the time for reviewing instructions, searching existing data sources, gathering and maintaining the data needed, and completing and reviewing the collection of information. Send comments regarding this burden estimate or any other aspect of this collection of information,

including suggestions for reducing this burden, to Washington Headquarters Services, Directorate for Information Operations and Reports, 1215 Jefferson Davis Highway, Suite 1204, Arlington

VA 22202-4302. Respondents should be aware that notwithstanding any other provision of law, no person shall be subject to a penalty for failing to comply with a collection of information if it

does not display a currently valid OMB control number.

1. REPORT DATE

JAN 2009

4. TITLE AND SUBTITLE

Final Environmental Assessment for the Space Complex-5 SCOUT

Launcher Relocation Vandenberg Air Force Base, California

6. $\operatorname{AUTHOR}(\mathrm{S})$

7. PERFORMING ORGANIZATION NAME(S) AND ADDRESS(ES)

30th Civil Engineer Squadron ,Environmental Flight, Vanden berg AFB,CA,93437

9. SPONSORING/MONITORING AGENCY NAME(S) AND ADDRESS(ES)
3. DATES COVERED

00-00-2009 to 00-00-2009

5a. CONTRACT NUMBER

5b. GRANT NUMBER

5c. PROGRAM ELEMENT NUMBER

5d. PROJECT NUMBER

5e. TASK NUMBER

5f. WORK UNIT NUMBER

8. PERFORMING ORGANIZATION REPORT NUMBER

10. SPONSOR/MONITOR'S ACRONYM(S)

11. SPONSOR/MONITOR'S REPORT NUMBER(S)

12. DISTRIBUTION/AVAILABILITY STATEMENT

Approved for public release; distribution unlimited

13. SUPPLEMENTARY NOTES

14. ABSTRACT

15. SUBJECT TERMS

16. SECURITY CLASSIFICATION OF: a. REPORT

unclassified b. ABSTRACT

unclassified c. THIS PAGE unclassified
17. LIMITATION OF ABSTRACT

Same as

Report (SAR)
18. NUMBER 19a. NAME OF

OF PAGES

29 


\section{Contents}

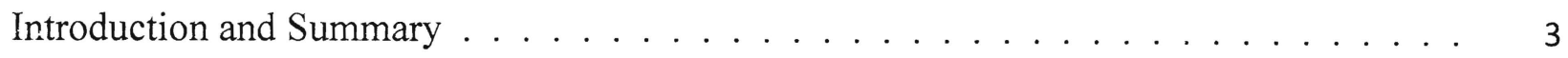

Purpose and Need for the Proposed Action . . . . . . . . . . . . . . . 5

Aiternatives Including the Proposed Action . . . . . . . . . . . . . . . . 6

The Proposed Action 6

$\begin{array}{ll}\text { No Action } & 7\end{array}$

The Affected Environment . . . . . . . . . . . . . . . . . . . 8

$\begin{array}{ll}\text { Background Information } & 8\end{array}$

$\begin{array}{lr}\text { Cultural Resources } & 8\end{array}$

$\begin{array}{lr}\text { Natural Resources } & 10\end{array}$

$\begin{array}{ll}\text { Potential Contaminants } & 10\end{array}$

Environmental ímpacts of the Proposed Action and No Action . . . . . . . . . . . . . 11

The Proposed Action $\quad 11$

Cultural Resources $1 \hat{i}$

Natural Resources $\quad 11$

Potential Contamination 11

$\begin{array}{ll}\text { No Action } & 12\end{array}$

Cultural Resources 12

$\begin{array}{ll}\text { Natural Resources } & 12\end{array}$

Potential Contamination $\quad 12$

$\begin{array}{ll}\text { Cumulative Effects } & 13\end{array}$

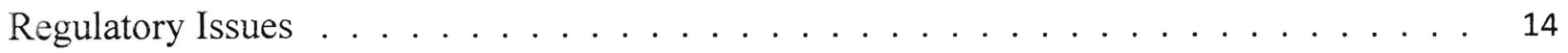

Agencies and Persons Consulted $\ldots \ldots \ldots \ldots \ldots$. . . . . . . . . . . 15

Finding of No Significant Impact $\ldots \ldots \ldots \ldots \ldots \ldots \ldots$

\section{List of Figures}

Figure 1. Photograph of SCOUT Launcher 4

Figure 2. SLC-5 Project Location $\quad 9$

Attachments

Attachment A: State Historic Preservation Officer Coordination 


\section{Final \\ Environmental Assessment for the Space Complex-5 SCOUT Launcher Relocation Vandenberg Air Force Base, California}

\section{Introduction and Summary}

The SCOUT, an acronym for Solid Controlled Orbital Utility Test, was the first U.S. launch vehicle to use solid fuel exclusively in all stages. The standard SCOLT is a four-stage vehicle approximately 75 feet in length, with an optional fifth stage available for launching smaller payloads into higher elliptical orbits. The SCOUT employs a dual-purpose launcher/transporter combination that permits checkout of the vehicle in the horizontal position and launching in the vertical position (Figure 1). The launcher has a movable base which permits azimuth control up to 140 degrees. A cantilevered elevating launch boom provides pitch control to the 90 -degree vertical position. There were originally two launch sites for the SCOUT - NASA`s Wallops Flight Facility on Wallops Island, VA, used for Eastern launches; and, Space Launch Complex 5 (SLC-5) at Vandenberg Air Force Base (VAFB), California, used for high inclination missions.

SLC-5 was built and used by the U.S. Naval Missile Facility Point Arguello at South VAFB. The first Navy launch from the SCOUT facility at SLC-5 was in 1962. After being used by the Navy for many years, the facility was transferred to the U.S. Air Force. The last Air Force launch from SLC - 5 was in 1994 - since then, SLC-5 has been unused.

The U.S. Navy proposes to remove the SCOUT Launcher and related appurtenances from VAFB. The launcher would be used at the Pacific Missile Range Facility (PMRF) in Hawaii to launch rail-guided vehicles of a size larger than the PMRF can currently launch in this manner. This program would be conducted in cooperation with the University of Hawaii Space Flight Laboratory (HSFL). The launcher would be refurbished at White Sands Missile Range (WSMR) prior to being transferred and reinstalled at the PMRF in Hawaii. Launcher-related appurtenances also proposed for relocation include the spin balance assembly, the erector, salvageable control panels and other electronic parts currently housed at SLC-5 previously used for the SCOUT launcher that are currently in salvageable condition. The Navy PMRF will assume ownership of the SCOUT Launcher and related equipment upon removal from SLC-5 at VAFB.

The SLC-5 site has been determined eligible for the National Register of Historic Places. As such, removal of the SCOUT Launcher from SLC-5 would adversely affect the historical value of SLC -5 . No other adverse affects are anticipated by this removal. SLC -5 suffered substantial vandalism during 2006-2007, and most of the rest of the facilities at SLC-5 are severely degraded, and currently of little salvageable, historic or serviceable value. Due to the degraded condition of SLC-5, VAFB has planned to demolish the entire SLC-5, salvaging useable portions and disposing of other buildings and materials as appropriate, then returning the site to its natural state. If the SCOUT Launcher is removed as proposed, and the adverse impact of that removal mitigated, further salvage and demolition actions at SLC-5 would have less potential for adverse affect than were the SCOUT launcher still in place. 


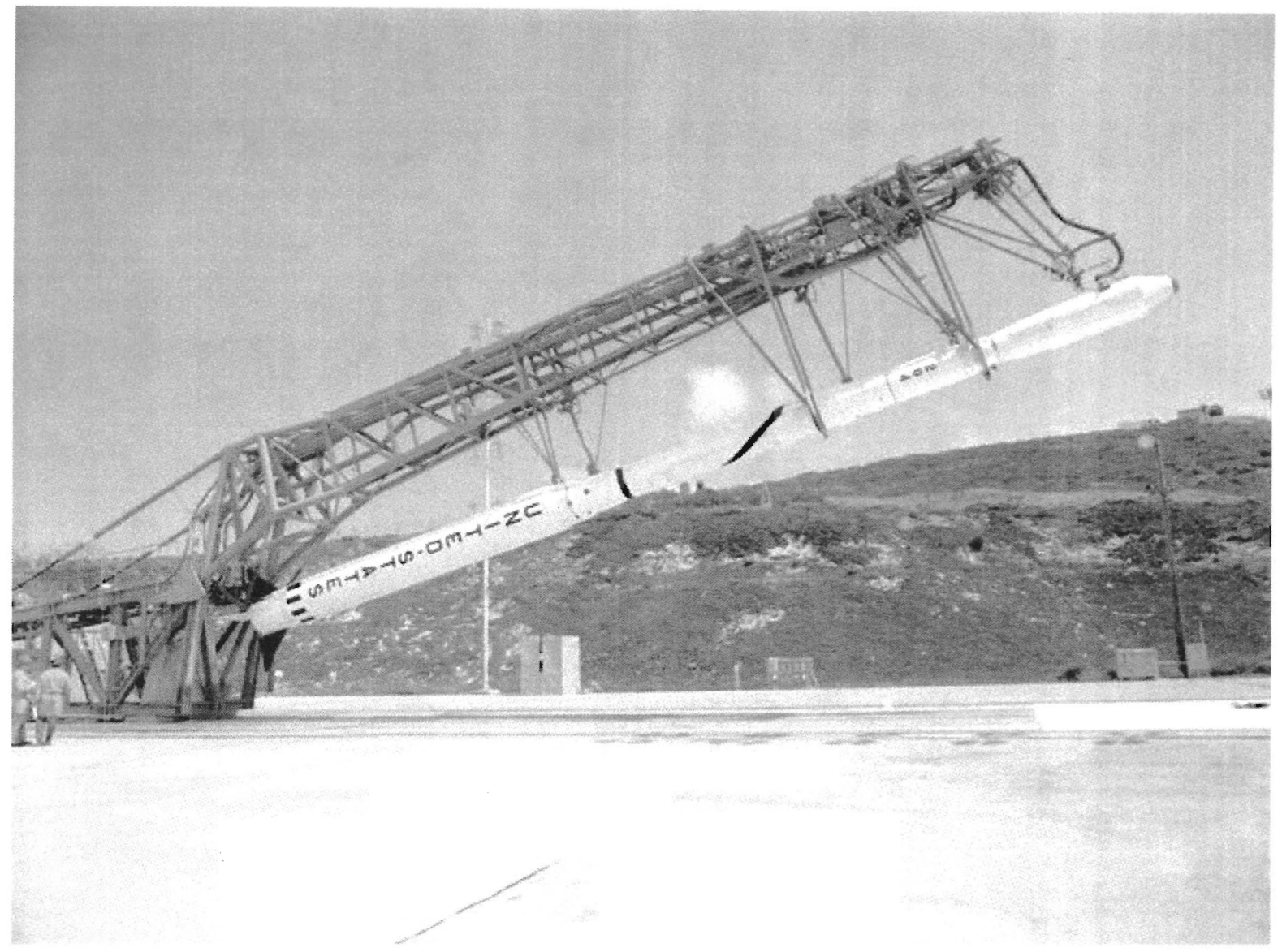

Figure 1. Photograph of SCOUT missile on Launcher being raised from a horizontal missile-readiness position to a vertical launch position. 


\section{Purpose and Need for the Proposed Action}

The United States advantage in space technology and trained space operations personnel is dwindling as more foreign governments make significant investments in orbital capability. The high cost of validating new technologies is primarily diriven by high launch costs. The HSFL, supported by the Operationally Responsive Space oftice, seeks to address this problem by adding the Low-Earth Orbit Nanosat-integrated Defense Autonomous System (LEONIDAS) to its program. As one of its primary goals, LEONIDAS would develop a rail-launched, spin-stabilized launch vehicie capable of placing smaii satellites into low-Earth orbit for technology demonstration missions at low cost. These technologies can then be incorporated into larger satellites or flown in a variety of other configurations from the HSFL.

The PMRF is the LEONIDAS-proposed location for the launch activity, owing to its geograpnic position allowing access to multiple favorable launch azimuths. The proposed LEONIDAS Iaunch vehicle is similar in size and weight to the family of SCOUT venicles previously launched trom VAFB SLC-5. PMRF's current 50K rail has been deemed insufficient to handle the preferred LEONIDAS launch vehicle load. The VAFB SCOUT Launcher, which is still intact and serviceable at SLC-5, would provide a significant upgrade from the 50K rail in terms of overall capacity to handle the LEONIDAS-proposed space vehicles at the PMRF.

The U.S. Navy proposes to un-install the SCOLT Launcher and related appurtenances from SLC5, reconfigure the launcher at WSMR, and re-install it at the PMRF for the LEONIDAS Program. Additionally, because of the desire for spin-stabilization of the LEONIDAS vehicle, the program proposes to also transfer the spin balance equipment in VAFB SLC-5 Building 995, as well as other related electronic panels if salvageable, as part of the SLC-5 SCOUT Launcher transfer. Removal, refurbishing and transferring the launcher and related appurtenances from SLC-5 to the PMRF has been determined significantly less expensive than constructing a new launcher with necessary appurtenances on site at the PMRF. 


\section{Alternatives Including the Proposed Action}

Alternatives, other than no action, to this proposal include removing the SCOUT launcher from SLC-5, but not for reuse at the PMRF (e.g., simply remove and store the launcher elsewhere, put it into a museum, or refurbish it and use it at a different facility): and'cr, rebuild SLC -5 . retaining the SCOUT Launcher for fiture use at SLC-5. Since there are no foreseeable propenents for preservation and/or display, or other launch-related uses of the SCOUT Launcher, either at SLC-5 or elsewhere, these alternatives are not considered practicable and thus are not evaluated further in this assessment. A No Action alternative (i.e., leaving the SCOUT launcher intact at SLC-5 and continuing to let the site deteriorate with no reclamation or reuse) is practicable, and thus is compared to the Proposed Action in this assessment.

The Proposed Action - Removal of the SCOUT Launcher from SLC-5 for reuse at the PMRF.

The PMRF, in association with WSMR and the HSFL, would disassemble the SCOUT Launcher at SLC-5 and transport the components via trucks to WSMR for renovation and modifications to support launch activities at the PMRF. The Spin Balance assembiy from Bldy 995 and some other salvageable equipment would also at that time be removed from SLC-5 and transported to Hawaii. This effort would include the following specific efforts:

1. Removal of the SCOUT Launcher interfaces, including electrical/control/data lines and gas piping.

2. Removal of the erector elevation mechanism and preservation for reuse.

3. Removal of the SCOUT transporter and preservation for reuse.

4. Removal of the boom structure in a manner which ensures capacity to re-assemble. This would require cutting of some structural members. The cutting would be accomplished through the use of mechanical as well as gas cutting methods. Full access to the boom for disassembly would require removal of a number of sections of service deck which surround the launcher.

5. Removal of the erector turntable assembly in a manner which ensures capacity for reassembly. Removal of the turntable assembly would require saw cutting and jack hammering concrete adjacent to the launch ring.

6. Removal of Spin Balance equipment from Bldg 995 in a manner which allows reassembly.

7. Preparation of launcher equipment for transport to WSMR and preparation of Spin Balance equipment for transport to Haw aii.

There is currently no electrical service to SLC-5; therefore, removal activities would require the use of portable generators transported to the site and used during the removal operations. A generator would be leased from a local equipment rental business for this time period. It is also anticipated that one or more portable cranes would be necessary for the launcher removal and placement of the launcher and other appurtenances onto trucks for transport from the site.

All equipment would be transported to and from VAFB by truck via Coast Road, and access VAFB at the West Ocean $A$ venue gate. The launcher and appurtenances would thence be transferred via appropriately designated routes to either WSMR or to the Port of Los Angeles for transport to Hawaii by ship. 
No Action - Leavirg the SCOUT Launcher and related equipment at SLC-5.

No Action would leave the launcher at SLC-5, and the existing conditions would remain for the foreseeable future. As noted above. SLC-5 was severely vandalized sometime during 2006-2007. Every structure and building was damaged. The extensive vandalism, in addition to the cumulative effects of disuse, low maintenance, and deterio:ation calised by weather, has made the repair and reuse of the launch facility economically impracticable. As such. a No Action alternative would likely only allow SLC-5 and related equipment, including the SCOUT Launcher and its appurtenances to remain onsite and eventually further deteriorate in place. 


\section{The Affected Environment}

\section{Background Information}

The proposed project would occur at SLC-5 on VAFB. VAFB is located on the South-Central coast of California, approximately halfway between San Diego and San Francisco. The 99,000acre base extends along approximately 35 miles of the Santa Barbara County coastline and varies in width from 5 to 15 miles. The Santa Ynez River divides North and South VAFB - State Highway 246, also named W. Ocean Avenue, runs along this corridor. Both North Base (VAFB north of 246) and South Base (VAFB south of 246) can be accessed from State Highway 246 through security gates.

SLC-5 is located on South Base as shown in Figure 2 near the Pacific Ocean coast. As noted above, the last Air Force launch from SLC-5 was in 1994 - since then, SLC-5 has been unused and allowed to deteriorate through lack of maintenance and security. In May 2007, VAFB Reai Estate personnel discovered that SLC-5 had been damaged by an unknown person or persons. Subsequent investigations revealed that the vandal(s) entered the complex one or more times between late December 2006 and May 2007. Every structure and building was damaged - doors were forced open, interior wails had holes gouged in them, lighting was smashed, electronic control panels were destroyed, furnizure was broken and overturned, files were strewn on the floors, and neariy every glass partition inside the buildings and every exterior window pane was shattered. The extensive vandalism, in addition to the cumulative effects if disuse, low maintenance and weather-caused deterioration have made the repair and reuse of the SLC-5 facility uniikeiy without a proponent to rebuild the facility for re-continued use at VAFB. As a result, it nas been planned that VAFB demolish SLC-5 and salvage portions of the site for reuse elsewhere.

\section{Cultural Resources}

The SLC-5 site has been determined eligible for the National Register of Historic Places, and thus the site, including the SCOUT Launcher, nas potentially significant culturai vaiue. in addition to the historical value of SLC-5 and the SCOLT Launcher, two prehistoric sites are located partly or completely within the SLC-5 site as noted in the attached State Historic Preservation Officer (SHPO) Memorandum of Agreement transmittal letter (Attachment A). One site is thought to be a temporary hunting/flintworking site - a 1970 Site Form documented that this site had been completely destroyed through construction of SLC-5. In sum, reliable documentation indicates that the site currently has no integrity. A second prehistoric site. located partially within the SLC5 boundary was first recorded in 1988 . Following site testing, a 1990 Site Form concluded that this site was also predominately destroyed by construction of SLC-5 and had no research potential. The Section 106 consultation for the SCOUT Launcher removal (Attachment A) concluded that neither of these sites is eligible for listing in the National Register of Historic Properties and thus have no significant cultural value.

As also noted in Attachment A. SLC-5 is within the view -shed of the Juan Bautista de Anza National Historic Trail. This historic trail corridor passes within about 80 meters of the SLC-5 fence line. This trail corridor has significant cultural value. 


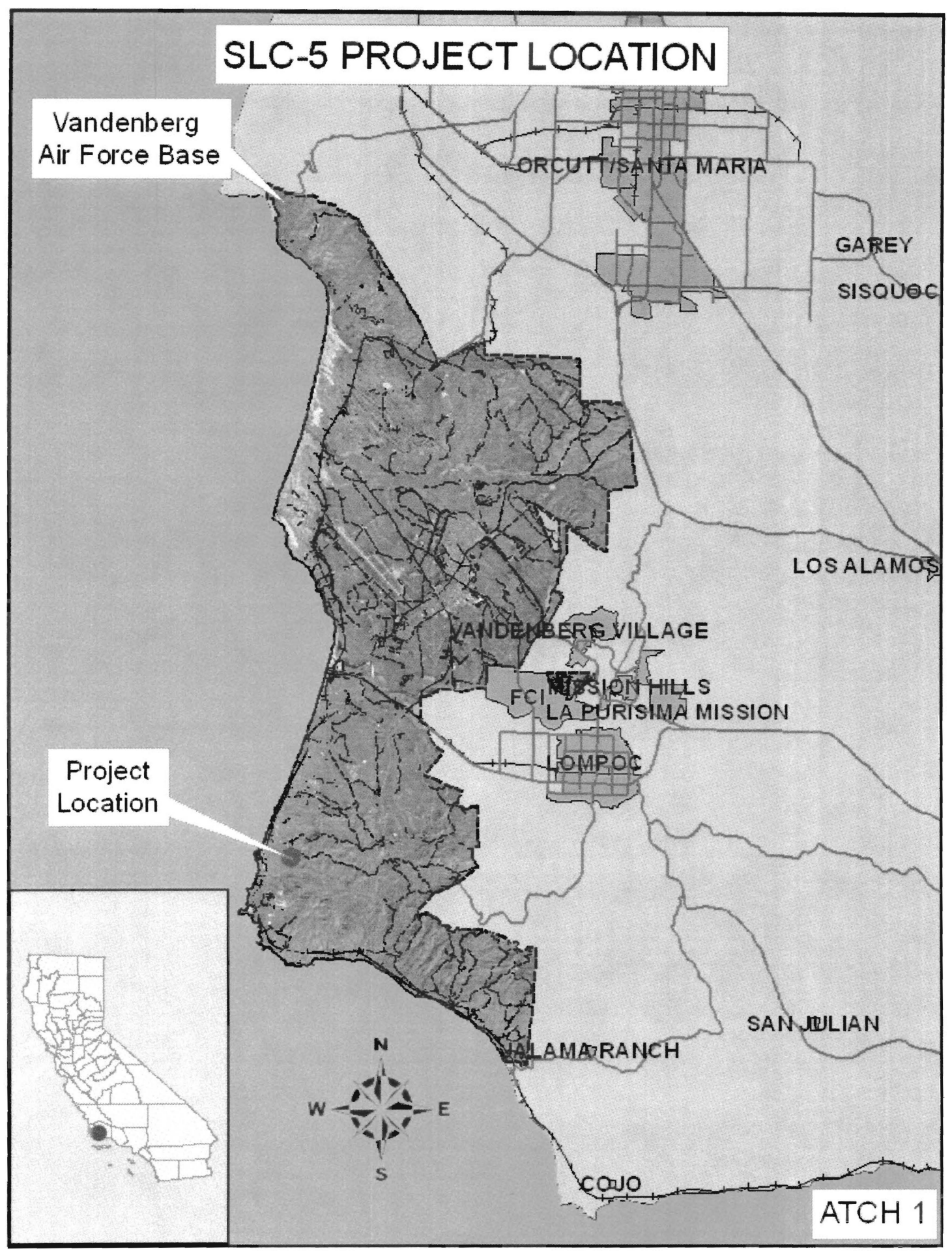

Figure 2. Proposed Project Location at SLC-5 


\section{Natural Resources}

The landscape surrounding SLC-5 and nearby environs is composed primarily of Central Coast Scrub with substantial areas dominated by non-native grasses and ruderal vegetation. Ruderal vegetation is found growing primarily adjacent to roads and other areas subject to frequent disturbance and is dominated by low-growing herbaceous species, most of which are non-native. These include iceplant. annual grasses and forbs. Nearby non-native grasslands are also found primarily in areas commoniy subjected to prior disturbance allowing weedy non-native species to invade the landscape. Iceplant also dominates this kind of vegetation type. Central Coast Scrub is the dominant native vegetation in the area. This landscape consists primarily of California sagebrush and coyote bush. One plant species, listed by the Fish and Wildlife Service as an endangered species in accordance with the Endangered Species Act (ESA), the Gaviota tarplant. is occasionally found in this area. Another sensitive native species, the seacliff buckwheat, is also present in limited quantities in this area. While not itself an endangered species, the buckwheat is, however, the host plant for an ESA-listed buttertly, the El Segundo Blue Butterfly. Because this endangered butterfly relies on this host plant for part of its life cycle, this buckwheat is generally treated as a protected species.

The SCOUT Launcher and related appurtenances are located entirely within developed portions of the SLC-5 complex. There is no natural habitat or native vegetation within the developed portions of this complex, and none of the launcher removal activities would occur outside developed portions of SLC-5, other than transportation of the removed items by truck along designated roadways. Some animals might occasionally be found in or near SLC-5, such as insects, birds, reptiles, andior amphibians. None of these that are likely to be very near or within the SLC-5 complex are, however, considered sensitive or protected species.

\section{Potential Contaminants}

Given the age of SLC-5, it is likely that asbestos and lead-based paint are present in some of the buildings. Samples of any structures that would require demolition to access and remove any salvageable appurtenances to the launcher would be taken prior to removal to determine the presence of such materials. If such substances are found in locations that would be disturbed, procedures for handling such materials would be coordinated with VAFB environmental staff to ensure management and/or disposal of such substances comply with Federal, State and other pertinent hazardous materials requirements.

There is a potential, given the historical use of various fuels and related chemicals for missile launches at SLC-5, that some of the soils within SLC-5 possess minor chemical contamination. The extent and/or level of such potential contamination has not been evaluated at this time. No other hazardous substances are suspected to be present at the project site. 


\section{Environmental Impacts of the Proposed Action and the No Action Alternative}

The proposed action and alternatives could result in foreseeable environmental consequences to cuitural resources. natural resources, contaminants, and cumulative effects. Each of these potential impacts is discussed for the two alternatives.

The Proposed Action - Removal of the Scout Launcher from SLC-5 for reuse at the PMRF.

Cultural Resources: The proposed action would allow the SCOUT Launcher to be rehabilitated and reused, thus preserving its historical value, although in a new location. While the historical integrity of SLC-5 would be lost from the removal of the launcher, the value of the launcher equipment itself would not. The proposed loss of the historical integrity of SLC-5 has been coordinated with the SHPO in accordance with Section 106 of the National Historic Preservation Act and 36 CRF Part 800 (Attachment A). As noted in this correspondence, the adverse historicai effect caused by removal of the SCOUT Launcher would also be mitigated by the aireadycompleted Historic American Engineering Record (HAER) documentation of SLC -5 and subsequent preservation of this documentation at the Library of Congress, the Nationai Park Service, and other interested parties as determined between SHPO and VAFB.

Two prehistoric sites are located partly or completely within the SLC-5 site; however, as discussed in Attachment A, these sites have been destroyed or have lost their integrity, and as such, no potential further alterations from the proposed action are considered adverse.

Also noted above, SLC-5 is within the view-shed of the Juan Bautista de Anza National Historic Trail. Removal of the Launcher and related appurtenances would not affect this trail, as this equipment is visually obscured from the trail by SLC -5 buildings. Removal of SLC -5 and returning the site to a natural state, which would be somewhat facilitated by the removal of the launcher, would however, have a positive effect on the natural view setting in relationship to this trail's historic value.

Natural Resources: Removal of the launcher and related equipment would render the remaining portions of SLC-5 of little value due to the vandalism and destruction of these facilities noted above. And since, as discussed above, there are no proponents to reuse any of the remaining structures or to rehabilitate and reuse SLC-5 for any other purpose, it is likely that VAFB would eventually demolish the site entirely and return it to a natural state aithough the time and certainty of this action is not currently known. Site recovery might be accomplished in a manner to prevent exotic species from invading the site and instead encourage, or directly affect, reestablishment of native plant species. If recovery was accomplished in such a manner, the result would substantial!y benefit natural resources in the vicinity of SLC-5.

Potential Contamination: Removal of the launcher and related equipment would potentially create minor air and water contamination and hazardou's naterials could be disturbed.

Portable gas or diesel powered generators would be used for electrical supply for equipment used in the removal. These generators would release minute quantities of air toxins common to these types of engines, contributing to regional and global concentrations of these air toxins, including those affecting global warming. Generators would be leased from a commercial rental agency near VAFB. It is expected that gas cutting equipment would also be used at the site - adding other minute quantities of air toxins to the local and regional atmosphere. As the equipment to be 
used for the proposed project is relatively smali and would be used for a very short time period, contributions of emissions to local or regional air quality degradation are presumed insignificant. To ensure such emissions are not excessive, the use of portable generators of $50 \mathrm{bhp}$ or greater, and gas-cutting equipment, requires registration issued by the California Air Resources Board or a permit to operate issued by the Santa Barbara County Air Pollution Control District. Should such permits or registration be required, the operators of such equipment for the proposed project would provide a copy of the permit/registration to the VAFB Environmental Compliance office (CEV/CEVC) prior to beginning the project and would need to maintain records detailing fuel usage and hours of operation. Since such equipment would be leased from a local agent, they would likely already be registered, but records as noted would still likely be required.

Any buildings or equipment that might require disturbance to facilitate removal of the launcher or related appurtenances where lead-based paint or asbestos might be found would be tested for such substances prior to disturbance. Should such substances be found potentially disturbed, any disturbance or disposal of such materials would be accomplished according to established guidelines to avoid significant hazards to human health. Testing and compliance with such guidelines would be coordinated with the VAFB Environmental Compliance office (CEV/CEVC).

None of the launcher removal activities are expected to disturb soils located within SLC-5; as such, any acute disturbances or releases of potential chemical soil contamination, as noted above, are not expected. In addition, long-term contamination of the area from potential rainwater runoff-carried contamination is also unlikely.

No Action - Leaving the Scout Launcher and related equipment at SLC-5.

Cultural Resources: This alternative would result in simply retaining the status quo at SLC-5 - in disrepair and without rehabilitation or maintenance - which would result in continued deterioration of the site. Eventually, salvageable values at the site would be lost or seriously degraded. This alternative would not directly remove the historical integrity of the launcher from the complex, but the launcher would likely eventually deteriorate. diminishing its current historical value.

Natural Resources: If the SCOUT Launcher is simply left in place and not used, rehabilitated or maintained, this alternative would constrain complete demolition of SLC-5 and returning the area to its natural state as some other kind of mitigation would be desirable for the loss of the launcher to preclude a significant historical impact. This alternative would thus inhibit a positive effect on natural resources of the area, as restoration of the site could potentially benefit the natural resources of the vicinity by increasing the availability of natural habitat to the area.

Potential Contamination: Allowing the SCOUT Launcher and related appurtenances to remain at SLC-5 would prevent any acute releases of air contaminants from the operation of launcher removal equipment. Any contributions of these contaminants to global warming would also be restrained by No Action. Because acute releases from the Proposed Action are minor and not significant, however, this benefit is not significant.

As leaving the SCOUT Launcher intact at SLC-5 would also likely constrain demolition of SLC5 , the slow deterioration of the physical structures at the site would likely cause a very minor, but long-term increase in stormwater water runoff, some wind erosion and possibly from further vandalism. The likelihood of lead-based paints, asbestos and soil contamination within areas of SLC-5 provides a probability that long-term degradation of the site through natural or man- 
induced sources might also include release of some of these toxins into the surrounding environment. The significance of this potential contamination is unpredictable at this time.

Continued lack of natural vegetation onsite would continue to decrease retention of natural rainwater onsite and increase stormwater runoff, thus inducing a continuation of increased erosion downstream of the site during high rainfall events. This erosion would cause minor losses of local soils. vegetation degradation and some sedimentation as the eroded soils eventually reach the ocean.

Precluding re-use of the launcher for the PMRF would also necessitate construction of a new launcher for use at PMRF, rather than rehabilitation of the materials found at SLC-5.

Construction of new launch equipment for use at the PMRF would likely create greater contributions of air and water contaminants than the rehabilitation of the launcher from SLC-5. New materials would have to be created at factories from raw materials mined at numerous locations throughout the world. Each of these individual operations would contribute small amounts of air and water contaminants at each of the sources of raw materials. Additionally, raw and constructed materials would be transported in numerous small shipments and then assembled and tested for use, creating multiple sources of contributions to transportation-related emissions. While enumerating specific or predictable amounts and/or sources of such contaminants are beyond the scope of this assessment, it is highly unlikely that such contamination would be greater than those associated with the proposed action. The Proposed Action requires little or no mining of raw materials, less construction, less shipping and packaging, and less overall manpower and materials testing that might release contaminants from a large variety of sources throughout the process.

\section{Cumulative Effects:}

There are other Cold War-era missile facilities being decommissioned, and/or in a state of deterioration. These facilities are usually recorded for historical purposes on a regular basis at both VAFB and at other locations, as justification for their continued use and maintenance becomes obsolete with advancing technologies and changing world politics. As such, removal of the historical value of the SCOUT Launcher from its original configuration, either by re-use or gradual deterioration, contributes somewhat to this changing use of missile and space technology infrastructure, concomitant diminishment of historical landscapes, and individualized changes to the natural air and water qualities, both locally and on a larger scale. Such changes are inevitable, as are other changes in the general historica! landscape that occur with advances in technology.

Neither the Proposed Action nor the No Action alternative is, however, expected to contribute significantly to such foreseeable accumulation of environmental effects. The Proposed Project's contribution to the loss of the launcher's historical significance would be mitigated in two ways: the historical value of SLC-5 has been recorded in accordance with the NHPA; and, the SCOLT Launcher would not te destroyed, but be reused elsewhere. The No Action alternative would likely have a greater impact, as the historical value of the launcher and SLC-5 would slowly degrade with no federal action occurring to require NHPA-required recording. This degradation would, however, occur over such a long time period that the significance of this loss in the foreseeable future is relatively minor. 


\section{Regulatory Issues}

The Air Force Environmental Impact Anaiysis Process (EIAP), culminating in this Environmental Assessment. ensures that relocation of the SCOUT Launcher Program is consistent with Federal, State and local laws and regulations and DoD and Air Force policy. The relevance of regulatory issues to this program include the following:

32 CFR Part 989, USAF Environmental Impact Analysis Process (EIAP). This part of 64 Federal Regulations 38129 implements the Air Force EIAP process. This document follows the guidelines outlined in these guidelines.

National Historic Preservation Act (NHPA). In accordance with Section 106 of the NHPA, this project was coordinated with the California State Historic Preservation Officer and a Memorandum of Agreement was reached allowing the project to proceed in compliance with the requirements of this Act (Attachment $\mathrm{A}$ ).

Endangered Species Act (ESA). In accordance with the ESA, the potential effects of the proposed action on threatened and endangered species in the vicinity of the project were evaluated - there were no adverse effects found likely from either the proposed action or the No Action alternative, therefore consultation with the FWS and/or NOAA is not required.

The Clean Water Act. Regulates discharge of point and non-point pollutants into waters of the U.S. There are no anticipated discharges of any pollutants from either the proposed action or the no action altemative that would enter waters of the U.S. Any work at SLC-5 related to the proposed action would not increase runoff from a rainfall event should it occur during removal operations.

The Clean Air Act. Regulates releases of contaminants into the air, requiring that such emissions comply with applicable requirements. There would be some minor releases of emissions from the portable generators and gas cutting equipment operated at SLC-5 during the launcher removal. Operation of such equipment would be conducted in accordance with regulations promulgated by the Santa Barbara County Air Pollution Control District, as appropriate.

Coastal Zone Management Act. Requires that any federal action that may affect the coastal zone must be consistent with the State Coastal Zone Management program. The proposed action would not affect any aspects of the Coastal Zone, as removal of the SCOLT Launcher would not result in the loss of, nor the additions of, any structures visible from the Coastal Zone, nor create any air or water quality emissions affecting the Coastal Zone.

E.O. 12898 Environmental Justice. Requires that Federal agencies identify and address disproportionately high and adverse human health or environmental effects of its programs, policies and activities on minority populations and low-income populations. The proposed action is not expected to affect human health or environmental effects on any such populations. 


\section{Agencies and Persons Consulted}

\section{Contributors to the EIAP Process}

\section{0th Space Wing, 30 CES/CEV Personnel:}

Carucci, James, Ph.D., Cold War Architectural Historian, VAFB

Case, Kevin, Hazardous Waste Program, VAFB

Domako, Kenneth, Environmental Planning Chief, VAFB

Evans, Rhy's, Natural Resources Program, VAFB

Maloy, Patrick, Solid Waste Program, VAFB

Narciso, Danilo. Hazardous Materials Program, VAFB

Nathe, Craig, Installation Restoration Program, VAFB

Rieger, Phillip, Ph.D., EA Primary Author, Environmental Planning, VAFB

Wiskowski, Tara, Water Resources, VAFB

30th Space Wing, XPR:

Perkins, Scott, Major, USAF, Programs and Planning, VAFB

U.S. Navy, Pacific Missile Range Facility:

Bran, Nando, Launch Ordnance Systems

University of Hawaii, Space Flight Laboratory:

Flynn, Luke, Ph.D., Director, HSFL

Williams, Tim, Spectral Technology Group, Hawaii Institute of Geophysics

and Planetology/School of Ocean and Earth Science and Technology

\section{Regulatory Coordination}

Donaldson, Miiford, State Historic Preservation Officer, State of California

\section{Public Coordination}

The public comment period for this EA is from January 17, 2009 through February 17, 2009. Comments may be sent to $30 \mathrm{CES} / \mathrm{CEV}, 1028$ Iceland Avenue, Vandenberg AFB CA 93437; or, faxed to 805/606-7407. If you have any questions, piease contact Dr. Phillip Rieger at 805/605-0331. 


\section{Finding of No Significant Impact}

Upon evaluating the analyses reflecting the affected environment and likely environmental consequences of the Proposed Action presented in this EA, I find that no significant impacts would result from implementation of the Proposed Action. There are no emissions that would have more than a negligible effect on air or water quality, and appropriate Federal and State regulations will be complied with to ensure that such is the case. The proposal would not affect the Coastal Zone, as defined in appropriate State regulations, nor would the proposal result in the release or disturbance of any contaminants affecting human health or the environment. All relevant regulatory issues have been considered and will be complied with as appropriate.

The Proposed Action would affect one potentially significant environmental resource - a historic property. The proposed action would remove the SCOUT Launcher and Erector with related appurtenances, which are eligible as Cold War-era space facilities, from SLC-5. As such, in accordance with Section 106 of the National Historic Preservation Act, the Department of the Air Force, Vandenberg Air Force Base, entered into a Memorandum of Agreement (MOA) with the California State Historic Preservation Officer. The purpose of this MOA is to ensure this adverse effect is mitigated by Level II Historic American Engineering Record Documentation and other related actions noted in the MOA. The California State Historic Preservation Officer concurred with the MOA in a letter dated November 24, 2008, which is attached to this EA.

I conclude that this EA has been properly prepared in accordance with the National Environmental Policy Act of 1969, as implemented by 32 CFR Part 989 for the U.S. Air Force Environmental Impact Analysis Process. This EA has been coordinated with appropriate Federal and State agencies and with the public, as required by these regulations.

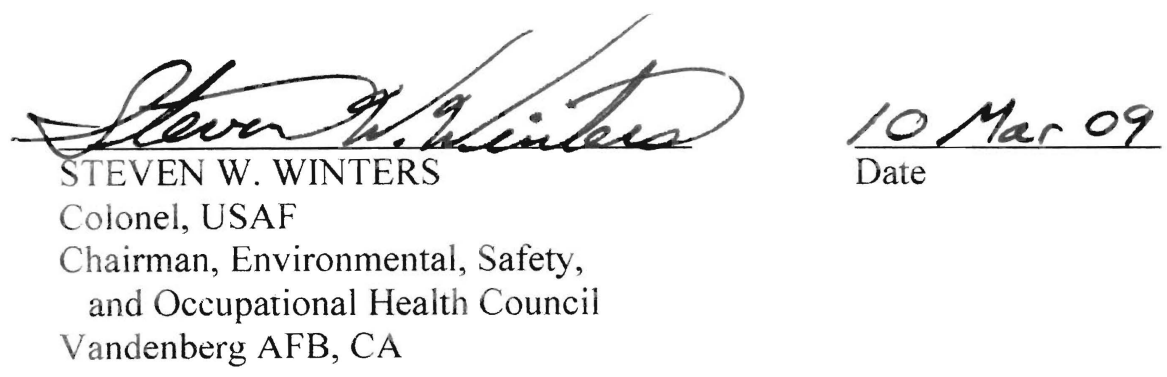




\section{ATTACHMENT A \\ STATE HISTORIC PRESERVATION OFFICER COORDINATION}

for the

Space Complex-5 SCOUT Launcher Relocation EA

Vandenberg Air Force Base, California

INCLUDING:

1. Letter of Transmittal for Memorandum of Agreement (6pp);

2. Memorandum of Agreement (4pp); and,

3. Letter of Concurrence from the State Historic Preservation Officer (2pp). 


\section{DEPARTMENT OF THE AIR FORCE \\ 3OTH SPACE WING (AFSPC)}

Richard N. Cote

$30 \mathrm{CES} / \mathrm{CD}$

1172 Iceland Ave

Vandenberg AFB CA $93437-6012$

Mr. Milford Wayne Donaldson

State Historic Preservation Officer

Department of Parks and Recreation

Office of Historic Preservation

P.O. Box 942896

Sacramento CA 94296-0001

Dear Mr. Donaldson

In accordance with Section 106 of the National Historic Preservation Act (NHPA) and 36 CFR Part 800, the Department of the Air Force, Vandenberg Air Force Base (VAFB), is advising you of a proposed undertaking that will affect a historic property. The property in question is the Cold War-era Space Launch Complex 5 (SLC-5), and the undertaking is the "Demolition and Salvage of SLC-5." The complex is located on South VAFB in Santa Barbara County (Atch 1), and has not been used since 1994. SLC-5 received minimal maintenance for the last several years, and many of the facilities were damaged by inclement weather and other destructive forces. Because no new mission was identified for SLC-5. and because of its poor physical condition, VAFB plans to demolish the facility and salvage portions of the launcher hardware for reuse elsewhere. This consultation combines a discussion of the Area of Potential Effects (APE) for the demolition undertaking and our Determination of Eligibility for two prehistoric properties (per 36 CFR 800.4) with our finding of Adverse Effect.

\section{Background Information}

SLC-S is a Scout vehicle launch complex that was built and used by the U.S. Naval Missile Facility Point Arguello (NMFPA). The NMFPA occupied an area that is now South VAFB and the first Navy launch from the Scout facility was in 1962; the last Air Force launch from SLC-5 was in 1994. In the intervening years, the Scout launch vehicle achieved a number of important milestones involving Navy, NASA, Defense Department, and Air Force programs. Detailed historical information and architectural descriptions of the facilities that comprise SLC-5 are provided in Attachment 2. An aerial view of the SLC-5 area is also included. Derived from the VAFB Geographic Information System (GIS) database, the map show's physical features and historic properties in the vicinity of SLC-5 (Atch 3).

In May 2007, VAFB Real Estate personnel discovered that SLC-5 was damaged by an unknown person or persons. Subsequent investigations revealed that vandals entered the launch complex one or more times between late December 2006 and May 2007. Every structure and building was damaged; doors were forced open, interior walls had holes gouged in them, lighting was smashed, electronic control panels were destroyed, furniture was broken and overturned, files were strewn on the floors, and nearly every glass partition inside the buildings and every exterior window pane was shattered. The extensive vandalism (Atch 4) in addition to the cumulative effects of disuse, low maintenance, and deterioration caused by weather has made the repair and reuse of the launch facility unlikely. As a result, VAFB is planning to demolish Space Launch Complex 5. 


\section{4(a)(1) - Description of the Area of Potential Effects}

The proposed undertaking, the demolition of a launch complex, will affect only SLC -5. The Area of Potential Effects (APE) is defined as the entire compound, surrounded by a security fence, plus an additional work zone extending 30 meters beyond the fence (Atch 5). The APE is outlined in yellow in Attachment 5, and two Areas of Direct Impact (ADI) located mostly within the compound are outlined in black. The security fence (red outline) around the perimeter will be removed as well, and the fence itself is an additional, linear ADI. Direct impacts caused by the fence removal will be limited to a narrow corridor of a meter or less, centered on the fence.

The western ADi that encompasses the Blockhouse includes the asphalt entrance drives that are outside of the SLC-5 perimeter fence. These access roads, parking areas, and related improvements will be removed. However, all other planned removal activities will occur within the existing perimeter fence. The 30 meter-wide area between the APE boundary and the fence ADI is a precautionary buffer zone that will contain the actions of demolition equipment and heavy machinery, and any regrading activities that are deemed necessary at the end of the site clearing process.

\section{$800.4(c)(2)$ - Determination of Eligibility}

The SLC-5 demolition APE has been surveyed for buried archaeological deposits. There are two prehistoric archaeological sites within the A.PE or adjacent to it, and two others that are within about 200 meters. Site files and records maintained by VAFB indicate that eligibility for listing in the National Register of Historic Places (NRHP) is undetermined for the two sites nearest the APE.

The prehistoric archaeological sites located within or adjacent to the project APE are CA-SBA-538 and CA-SBA-2230. The first site, SBA-538, is situated just south of the launch shelter and entirely within the project APE. The earliest record of this site, dating to 1950 , describes it as a "sand blowout" measuring about 100 yards in diameter with artifacts on the deflated surface (Atch 6). Thought to be a "temporary hunting/flintworking site," a 1970 site form documented that SBA-538 had been "completely destroyed through construction of (the) launch complex." In 1982 the site could not be relocated and was again reported as "100 percent destroyed." In sum, reliable documentation indicates that CA-SBA-538 was destroyed during construction of SLC-5 in 1961-62 and currently has no integrity.

The second site is CA-SBA-2230, which is located at the west end of the SLC-5 complex adjacent to the security fence and partly within the APE. First recorded in 1988, the boundary of the site mapped at that time is essentially the same as the site outline shown in the VAFB GIS today. However, results from test excavations in 1990 suggested that a much smaller site area was appropriate. Completion of 33 shovel test pits and 8 excavation units recovered only "two biface fragments, 1 possibly utilized flake (and) debitage of Monterey chert." Field observations on site noted the presence of natural, unmodified chert cobbles and the description of artifacts on the updated 1990 site form states that "The mano noted in the original site record was located, collected, and determined to be non-cultural." Testing identified a lithic concentration about 90 meters south of the SLC-5 Blockhouse, and these data caused the contractor to recommend a much smaller site boundary. The summary of the 1990 testing project stated that the "research potential of this site has been exhausted" and that the site is not eligible for the NRHP. The latest site record from 1998 reports that the "Site has been destroyed by construction" (Atch 7).

\subsection{1(e)(1) - Description of the Undertaking}

The proposed undertaking is the demolition of SLC-5. All facilities and improvements within the existing perimeter fence, and the fence itself will be removed. Concrete foundations, exterior concrete and asphalt pads, access roads, staging and parking areas will be demolished and removed. Cable trays 
within the compound will be removed, as will aerial and belowground utilities. Outside of the APE, underground utility services will not be excavated or removed. Utility poles outside of the APE may be removed only if the poles are pulied and the holes filled without any impact to the surrounding soil.

The massive erector-launcher housed in Facility 580 (Atch 4) will be removed and returned to US Navy ownership for reuse at the Pacific Missile Range Facility (PMRF) in Hawaii. Other hardware and electronic control panels, although damaged, may be salvaged if they can be reused by existing launch programs. Any components or hardware not needed by active launch programs may be useful to the Air Force Museum or similar historic or interpretive venues. If feasible, items of use to museums or similar entities will be salvaged and transferred to them. The remaining hardware, facilities, and improvements will be salvaged for scrap or removed as waste material. After all the buildings, facilities, and civil improvements are demolished, the SLC-5 site will be rehabilitated and returned to a natural state.

\subsection{1(e)(2) - Identification of Historic Properties}

In 1997, personnel from the US Army Corps of Engineers Research Laboratory (CERL) in Champaign, IL completed a basewide survey of all VAFB buildings and facilities constructed or used during the Cold War. The CERL study collected historical data related to VAFB Cold War assets and the reports include summary architectural descriptions. The discussion of SLC-5 can be found in Volume I of the CERL study (Atch 2). That discussion identifies five facilities in the complex that are "contributing elements to the site," which all date to the Cold War era.

The CERL study also offered NRHP eligibility recommendations for VAFB Cold War assets. The findings from CERL were reviewed and modified by VAFB Cultural Resources staff, and two program management documents were written. After several drafts and extensive consultations with the SHPO, both a Programmatic Agreement (PA) and a Historic Preservation Plan (HPP) for the management of NRHP-eligible Cold War properties at VAFB were agreed on. The HPP streamlines NHPA consultation requirements for many common activities and processes affecting Cold War historic sites (Atch 8). The HPP also defines undertakings, such as demolition, that require formal Section 106 consultations.

The SLC-5 demolition APE has been surveyed for archaeological deposits. VAFB site records indicate that two prehistoric archaeological sites are located within or adjacent to the APE, and two others are about 200 meters away. In addition, the Juan Bautista de Anza National Historic Trail passes just west of SLC-5, about 80 meters beyond the fenceline. Farther away, a complex of prehistoric sites is located near the mouth of Honda Creek, and the "Honda Tragedy" naval disaster took place in 1923 on the rocky coast to the west-southwest of SLC-5. Attachment 3 is a GIS map and aerial photograph showing the nearby archaeological sites, Honda Creek, and other features in the SLC-5 vicinity.

\subsection{1(e)(3) - Deseription of the Affected Historic Properties}

The SLC-5 complex is composed of numerous separate structures, civil improvements, and other facilities, all of which will be demolished. Five facilities within the launch complex have been designated "contributing elements to the site." These contributing elements and the entire site complex are described in Attachment 2. The project APE map (Atch 5) illustrates the locations of the contributing elements, which are listed below:

Facility 580: Terminal Building / Launch Shelter

Facility 578: Cosmodyne Sheiter

Facility 579: Motor Building

Facility 582: Launcher Support Building

Facility 589: Blockhouse 
The Juan Bautista de Anza National Historic Trail stretches from southern Arizona to the San Francisco Bay. The Anza Trail passes through VAFB, and historical analysis places it on the marine terrace overlooking the ocean about 100 meters west of the SLC-5 blockhouse. The trail corridor marks the probable route taken in 1776 when Anza led a group of colonists through the area. The National Trail commenorates the passage of these settlers from Old Mexico north to San Francisco, and the trail corridor shown in Attachment 3 was determined by careful study of select ethnographic data, traveler's diaries, and other sources. However, there are no physical manifestations of the trail anywhere on VAFB.

The two prehistoric sites located partly or completely within the project APE are discussed in detail above. Our analysis indicates that CA-SBA-538 on the east, and CA-SBA-2230 on the west end have been destroyed or have lost their integrity. These sites are ineligible for listing in the NRHP and we request agreement from the SHPO on this finding.

\subsection{1(e)(4) - Effects of the Proposed Undertaking}

Because this proposed undertaking is a removal of the built environment, demolition of SLC-5 will have a positive effect on the natural setting in the immediate vicinity. Specifically, the viewshed that includes the Juan Bautista de Anza National Historic Trail will be enhanced by the proposed removal of the SLC-5 Cold War elements.

Archaeological site survey records indicate that SBA-538 on the east and SBA-2230 on the west end were destroyed by the construction of SLC-5. Demolition should not further impact the sites, although isolated, displaced artifacts may be encountered.

Demolition of SLC-5 is an Adverse Effect. A finding of Adverse Effect requires a Memorandum of Agreement (MOA) that defmes how the negative impacts of the proposed undertaking will be mitigated. The MOA and the proposed mitigation measures are discussed in more detail below.

\section{$800.11(\mathrm{e})(\mathbf{5})$ - Finding of Adverse Effect and Mitigation Actions to be Taken}

Based on the information presented in this letter, it is clear that the proposed demolition of SLC-5 constitutes an Adverse Effect. We have identified the following actions to be taken to mitigate the loss of Space Launch Complex 5:

a. Consultation with the Santa Ynez Band of Chumash Indians Elders Council shall be completed prior to any demolition activities. Representatives of the Elders Council shall be invited to monitor earth-disturbing activities during the demolition undertaking.

b. The undertaking will not directly impact any intact archaeological deposits. Portions of sites CA-SBA-538 and CA-SBA-2230 that were located within the APE have been destroyed; a concentration of lithics at SBA-2230 is outside the APE and will not be affected. Any unanticipated archaeological discoveries made during the demolition of SLC-5 shall be evaluated by VAFB Cultural Resources staff and the Native American monitors, and the actions specified in 36 CFR 800.13 shall be followed.

c. The SLC-5 erector/launcher shall be removed from Facility 580 and shipped to the PMRF in Hawail where it will be reconstructed and installed for reuse. Other launch hardware shall be salvaged for reuse as appropriate

d. An MOA has been prepared (Atch 9). The format and content of the MOA is the same as an MOA prepared by SHPO and VAFB in 2003, related to a similar project involving historic Cold War-era properties ("Ground Based Interceptor," SHPO log \# USAF030613A). 
e. A Historic American Engineering Record (HAER) documentation of SLC-5 shall be completed by VAFB. The HAER shall conform to Level II standards or above, and draft copies shall be offered to the appropriate National Park Service (NPS) and SHPO personnel for review. Final copies shall be offered to the Library of Congress, the NPS, SHPO, and other interested parties as determined by consultation between SHPO and VAFB.

f. Once this consultation has been received by the SHPO, VAFB shall forward a copy of this letter and its attachments to the Advisory Council on Historic Preservation (ACHP). Once the ACHP has been advised of the Adverse Effect, any comments or communications between VAFB and the ACHP shall be copied to the SHPO.

g. VAFB may erect a marker or monument at the site of the SLC-5 complex after the facilities have been demolished and removed. Also, VAFB may produce a descriptive brochure detailing the Cold War history of SLC-5. The brochure would be a helpful interpretive tool and it would be more easily shared with the interested public than the full HAER document.

\section{$800.11(e)(6)$ - Views of the Public/Consulting Parties}

The local VAFB community and members of the public interested in Cold War history are generally aware of the NRHP status of Cold War facilities on base. VAFB cultural resources staff gives numerous informal talks and other more official presentations each year that describe the important role played by Vandenberg during the Cold War. In addition, many interested parties are aware of the conditions at SLC-5, and most understand that the launch complex has stood vacant for years because no modern launch mission could be assigned to the site. Also, retired aerospace contractors and retired Air Force Personnel with knowledge of SLC-5 operations are being contacted and asked to provide personal stories and other oral-historical information about the Scout launch facility.

The local Native American community is consulted on a regular basis regarding their concerns and the potential impacts of federal undertakings at VAFB. The Native American group most closely associated with VAFB is the Chumash. Historic records and archaeological evidence both indicate that the Chumash occupation of the area has considerable antiquity and continuity. Currently, many Chumash descendents live on the nearby Santa Ynez Reservation. The Santa Ynez Band is federally recognized and Vandenberg maintains a Nation-to-Nation relationship with them. Personnel of the VAFB Cultural Resources Section meet regularly with the Chumash Elders Council. Monitoring ground disturbance during the demolition of SLC-5 will be discussed with Chumash tribal representatives at the next scheduled meeting.

Also consulted was a draft report that documents Traditional Cultural Properties (TCPs) and summarizes the ethnohistoric and ethnographic context of sacred and traditional sites in the VAFB area. In addition to discussing TCPs, the document identifies resource-gathering areas and other places of concern located within the boundaries of the installation. Based on the draft report and on past interviews with Chumash elders, there are no TCPS or resource-gathering areas that will be affected by the SLC-5 demolition undertaking.

\section{$800.11($ ) - Memorandum of Agreement}

A two-party MOA was prepared that exactly follows the format and basic content of a similar Cold War properties MOA from several years ago. Although it is a draft, it was signed by the VAFB Deputy Civil Engineer in an effort to save time. We hope that reuse of a successful MOA format from a previous consultation will greatly streamline the review process. 


\title{
Summary
}

This undertaking will have No Adverse Effect on the Juan Bautista de Anza National Historic Trail that passes near SLC-5. And the undertaking will have No Adverse Effect on prehistoric archaeological sites in or near the project APE. The latter statement is true for two reasons; first, our analysis shows that sites CA-SBA-2230 and CA-SBA-538 were destroyed when SLC-5 was constructed and are not eligible for the NRHP. Second, even if the ineligibility of these sites is questioned, the demolition activities will not materially affect undisturbed buried deposits associated with either site. Some stray artifacts possibly may be found in the area, but stratified and scientifically significant deposits are absent at both locations.

This undertaking will have an Adverse Effect on historic Cold War-era resources at VAFB. The "Demolition and Salvage of SLC-5" will completely remove the NRHP-eligible launch complex from the landscape. Loss of this property shall be mitigated by Level II HAER documentation and a number of other related actions. A MOA was prepared, which lists the mitigation actions.

Your signature and date on the attached MOA will indicate concurrence with our findings for this undertaking and with the stipulations in the MOA. If you wish to modify the (draft) MOA, please do so, and then transmit the updated copy to Dr.James Carucci (James.Carucci@vandenberg.af.mil). If you have any questions, please contact Dr. Carucci (805-606-2860) or Mr. Tom de Venoge (805-605-8684).

\section{Sincerely}

RICHARD N. COTE, P.E., YF-03, DAF

Deputy Base Civil Engineer

\author{
Attachments: \\ Project Locator Map \\ 2. Excerpted Historical Information \\ Aerial View of the SLC-5 Project Area \\ Current Condition of SLC- 5 \\ Map of SLC-5 APE with Structures Identified \\ 6. CA-SBA-538 Site Forms \\ 7. CA-SBA-2230 Site Forms \\ 8. Programmatic Agreement and Historic Preservation Plan \\ 9. Two-party MOA \\ cc: \\ HQ AFSPC/CEV w/o Atch \\ $30 \mathrm{CES} / \mathrm{CEV} / \mathrm{CEVPC}$ w/o Atch
}




\section{MEMORANDUM OF AGREEMENT \\ BETWEEN \\ VANDENBERG AIR FORCE BASE, CALIFORNIA \\ AND THE \\ CALIFORNIA STATE HISTORIC PRESERVATION OFFICER REGARDING THE DEMOLITION AND SALVAGE OF SPACE LAUNCH COMPLEX 5}

WHEREAS, Vandenberg Air Force Base (VAFB), California, proposes to demolish Space Launch Complex 5 (SLC-5), recycling some launch hardware for reuse (Undertaking); and

WHEREAS, VAFB has determined that the Demolition and Salvage of SLC-5 Undertaking will have an adverse effect on SLC-5 and no adverse effect on the Juan Bautista de Anza National Historic Trail or any other historic properties (including two prehistoric archaeological sites, SBA-538 and SBA-2230); and

WHEREAS, VAFB and the California State Historic Preservation Officer (SHPO) executed on July 19 , 2002, a Programmatic Agreement (Underlying PA) stipulating that Cold War properties significant for their distinctive physical characteristics and their historic function require completion of the statutory National Historic Preservation Act (NIPA) Section 106 consultation process prescribed by 36 CFR Part 800 when the physical integrity of the property is compromised; and

WHEREAS, VAFB has therefore consulted with the SHPO regarding the Demolition and Salvage of SLC-5 Undertaking, notified the Advisory Council on Historic Preservation (ACHP) of the adverse effect finding in accordance with 36 CFR Part 800 regulations effective August 5, 2004 implementing Section 106 of the NHPA, as amended (16 U.S.C. 470, et seq.), and proposes to resolve the adverse effect of the SIC-5 Demolition Undertaking by executing and implementing this Memorandum of Agreement (MOA);

NOW, THEREFORE, VAFB and the SHPO agree that the Demolition and Salvage of SLC-5 Undertaking shall be implemented in accordance with the following stipulations in order to take into account the effects of the SLC.5 Undertaking on historic properties, and that these stipulations shall govern the Lndertaking and all of its parts until this MOA expires or is terminated.

\section{Stipulations}

VAFB will ensure that the following measures are carried out:

I. AREA OF POTENTIAL EFFECTS

For the Demolition and Salvage of SLC-5 Undertaking, the Area of Potential Effects (APE) includes the entire SLC-5 complex within the security fence, the fence itself, and an additional work zone extending 30 meters beyond the fence. Details of this all-inclusive APE are given in the Section 106 consultation package VAFB sent to SHPO under separate cover.

11. RECORDATION

VAFB shall ensure that SLC-5 is documented in accordance with the standards of the HAER program, fulfilling the requirements of Level II documentation. VAFB shall offer an archival copy to the Library of Congress, and a working copy of the HAER to SHPO, the National Park Service, and other interested parties as determined by VAFB in consultation with SHPO. 
III. SALVAGE AND REUSE OF LAUNCH HARDWARE

Salvage of SLC.5 may begin after the HAER fieldwork is completed. The Erector/Launcher will be removed from Facility 580 prior to demolition, and offered to the Pacific Missile Range Facility (PMRE) in Hawaii. If the Erector/Launcher is no longer required by the U.S. Navy or the PMRF it may be offored to other military services or federal agencies. Other salvageable launch hardware may be removed from SLC-5 prior to demolition and transferred to the appropriate service or agency for reuse. After all possible salvage has occurred, and after SLC-5 has been demolished, there shall be no further requirement for mitigation or management of the site as a Cold War-era property that is eligible for listing in the National Register of Historic Places (NRHP).

\section{DISCOVERIES AND UNANTICIPATED EFFECTS}

If VAFB determines after construction has commenced, that the Demolition and Salvage of SLC-5 Undertaking will affect a previously unidentified property that may be eligible for inclusion in the NRHP or affect a known historic property in an unanticipated manner, VAFB will address the discovery or unanticipated effect in accordance with 36 CFR $\$ 800.13$ (b) (3). VAFB may assume the discovered property to be eligible for the NRHP, in accordance with 36 CFR $\S 800.13$ (c).

\section{RESOLVING OBJECTIONS}

A. Should the SHPO object to the manner in which the terms of this MOA are implemented, to any action carried out or proposed with respect to implementation of the MOA (other than the SLC-5 Undertaking itselD, or to any documentation prepared in accordance with and subject to the terms of this MOA. VAFB shall immediately consult with the SHPO for no more than 14 days to resolve the objection. VAFB shall reasonably determine when this consultation will commence.

If the objection is resolved through such consultation, the disputed action may proceed according to the terms of that resolution. If, after initiating consultation, VAFB determines that the objection camot be resolved through consultation, then VAFB shall forward all documentation relevant to the objection to the ACHP, including VAFB's proposed response to the objection, with the expectation that the ACHP will within thirty (30) days after receipt of such documentation:

1. advise VAFB that the ACHP concurs in VAFB's proposed response to the objection, whereupon VAFB will respond to the objection accordingly: or

2. provide VAFB with recommendations, which VAFB will take into account in reaching a final decision regarding its response to the objection; or

3. notify VAFB that the objection will be referred for comment pursuant to $36 \mathrm{CFR} \S$ 800.7 (a) (4), and proceed to refer the objection and comment. VAFB shall take the resulting comments into account in accordance with 36 CFR $800.7(c)(4)$ and Section H10(1) of the NHPA.

B. Should the ACHP not exercise one of the foregoing options within 30 days after receipt of all pertinent documentation, VAFB may assume that the ACHP has concurred with its proposed response to the objection.

C. VAFB shall take into account any $A C H P$ recommendation or comment provided in accordance with this stipulation only in reference to the subject of the objection. VAFB's responsibility to carry out all actions under this MOA that are not the subjects of the objection shall remain unchanged. 
D. VAFB shall provide the SHPO and ACHP, when the ACHP has issued comments hereunder, with a copy of its final written decision regarding any objection addressed pursuant to this stipulation.

E. VAFB may authorize any action subject to objection under this stipulation to proceed after the objection has been resolved in accordance with the terms of this stipulation.

F. At any time during implementation of the measures stipulated in this MOA should an objection pertaining to such implementation be raised by a member of the public, VAFB shall notify the SHPO in writing of the objection, and take the objection into consideration. VAFB shall consult with the objecting party, and if the objecting party so requests, with the SHPO, for no more than 15 days. Within 10 days following closure of the consultation period, VAFB will render a decision regarding the objection and notify the consulting parties of this decision in writing. In reaching its decision, VAFB will take any comments from the consulting parties, including the objecting party, into account. VAFB's decision regarding resolution of the objection will be final.

\section{AMENDMENTS}

VAFB or the SHPO may propose that this MOA be amended, whereupon these parties consult for no more than 30 days to consider such amendment. The amendment process shall comply with 36 CPR $\$ \$ 800.6(\mathrm{c})(1)$ and $800.6(\mathrm{c})(7)$. This MOA may be amended only upon the written agreement of VAFB and the SHPO. If it is not amended, this MOA may be terminated by either signatory party in accordance with stipulation VII.

\section{TERMINATION}

A. If this MOA is not amended as provided for in stipulation VI, or if either signatory party proposes termination of this MOA for other reasons, the signatory party proposing termination shall, in writing, notify the other signatory party, explain the reasons for proposing termination, and consult with that signatory party for at least 30 days to seek alternatives to termination. Such consultation shall not be required if VAFB proposes termination because the Demolition and Salvage of SLC-5 Undertaking no longer meets the definition set forth in 36 CFR $\$ 800.16(\mathrm{y})$.

B. Should such consultation result in an agreement on an alternative to termination, then the parties shall proceed in accordance with the terms of that agreement.

C. Should such consultation fail, the signatory party proposing termination may terminate this $\mathrm{MOA}$ by promptly notifying the other signatory party in writing. Termination hereunder shall render this MOA without further force or effect.

D. If this MOA is terminated hereunder, and if VAFB determines that the SLC-5 Undertaking will nonetheless proceed, then VAFB shall either consult in accordance with 36 CFR $\$ 800.6$ to develop a new MOA or request the comments of the ACHP pursuant to 36 CFR Part 800.

VIII. DURATION OF TIIE MOA

A. Unless terminated pursuant to stipulation VII., or unless it is superseded by an amended MOA, this MOA will be in effect following execution by VAFB and the SHPO until VAFB, in consultation with the SHPO, determines that all of its stipulations have been satisfactorily fulfilled. This MOA will terminate and have no further force or effect on the day that VAFB notifies the SHPO in writing of its determination that all stipulations of this MOA have been satisfactorily fulfilled. 
B. The terms of this MOA shall be satisfactorily fulfilled within 5 years following the date of execution by VAFB and the SHPO. If V AFB determines that this requirement cannot be met. $\checkmark A F B$ and the SHPO will consult to reconsider its terms. Reconsideration may include continuation of the MOA as originally execured amendment or termination. In the event of termination. VAFB will comply with stipuiation VII. D. if it is determined that the SLC-5 Undertaking will proceec notw ithstanding termination of this MOA.

C. If the Demolition and Salvege of SLC.5 Underraking has not been implemented within 5 years following execution of this MOA by VAFB and the SHPO, this MOA shall automatically terminate and have no further force or effect. In such event. VAFB shall notify the SHPO in. whting and, if VAFB chooses to continue with the SI.C.E Undertaking, it shall reinitiate reviex of the SLC.5 Undertaking in accordance with 36 CER Part 800.

\section{EFECTIEDATE}

This MOA will iake effect immediately upon execution by VAFB and the SHDO

EXECLTION of this MOA by VAFB and the SHPO, its transmittal by VAFB to the ACHP in accordance with 36 CFR $\$ 800.6$ (b)(1)(iv), anc subsequent implementation of its terms. shall evdence, pursuant 1036 CFR $800.6(\mathrm{c})$, that this $\mathrm{MOA}$ is an agreement with the ACHP for purposes of Section 110 ll of the NHPA, that WAFB has satisfactorily complied with the Widerlying PA, that VAFE has afforded the ACHP an opportunity to comment on the SLC.5 Whenaking an its effect on historic properties. and tha: VAEB has tahen into account the effewts of the SWC-E ndertaking on histaric properties

\section{SIN PARTES}

WDENBERG AIR FORCE BASE

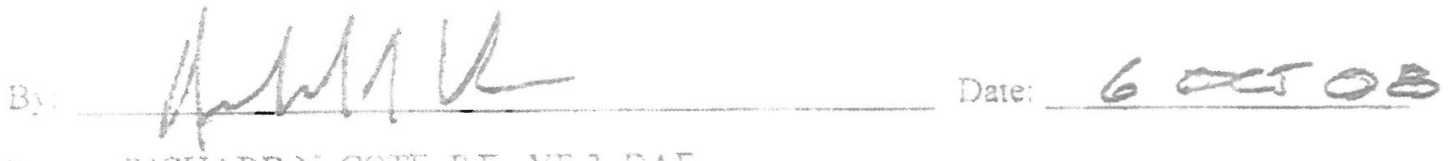

\am: RICHARD A. COTE, P.E. YF-3. DAF

Titie: Deputy Base Civil Engineer

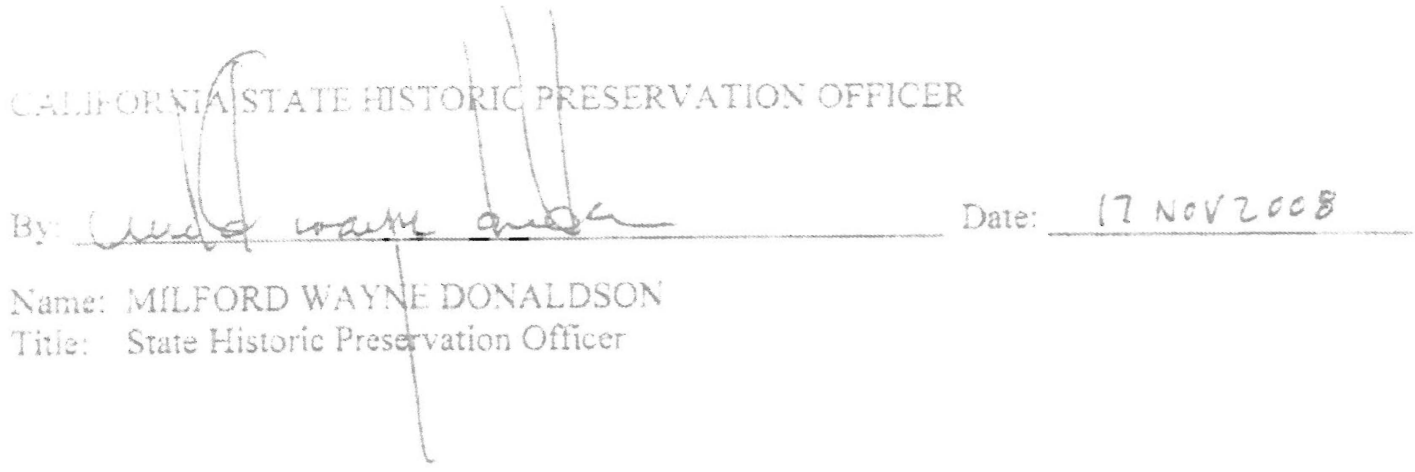




\section{OFFICE OF HISTORIC PRESERVATION DEPARTMENT OF PARKS AND RECREATION \\ P.O. BOX 942896 \\ SACRAMENTO, CA 94296-0001 \\ (816) 653-6824 Fax: (918) 653.9824 \\ calshpogoho parks ca.gov \\ www.ohp.parks.ca.gov}

November 24,2008

In reply refer to: USAF081009A

\author{
Richard N. Cote \\ 30 CES/CD \\ 1172 Iceland Ave \\ Vandenberg AFB, California 93437-6012
}

Re: Demolition and Salvage of Cold War Era Space Launch Complex 5 (SLC-5)

Dear Mr Cote:

Thank you for your letter dated 06 October 2008 regarding the above referenced undertaking. You are consulting with me in order to comply with Section 106 of the National Historic Preservation Act of 1966 (16 U.S.C. 470 ) as amended, and its implementing regulations codified at 36 CFR 800 .

Your letter informs me that the Air Force proposes to demolish the SLC-5 facility and salvage portions of the launcher hardware. This is due to a lack of new missions identified for the facility and its current poor physical condition. You request my concurrence with the Area of Potential Effect (APE) as defined by the Air Force, and the finding of adverse effect as a result of project implementation.

The SLC-5 facility was vandalized on a number of occasions between December of 2006 and May of 2007. This vandalism resulted in damage to every structure and building at the facility. The damage, coupled with the cumulative effects of disuse, low maintenance and deterioration has made the repair and reuse of the facility unlikely. You have submitted several attachments to your letter to aid in my review of the demolition of the facility. One of these documents explains the significance of the facility and states that SLC-5 was determined eligible to the NRHP based on the fact that it was a "unique launch complex that directly supported operational missions of the exceptionally important Cold War program."

You have also submitted a map that outlines the project area, the SLC-5 facility and a number of prehistoric archaeological sites that are located either within the APE or immediately adjacent to it. Further you have submitted copies of testing reports and site records for the two sites that are within the APE. Based on the materials you have submitted, I agree that the Air Force has properly determined and documented the APE and that your efforts to identify historic properties within the APE were appropriate. I also concur with your finding of adverse effect for the removal of the SLC-5 facility and agree with the stipulations you have provided within the Memorandum of Agreement (MOA) that you sent as mitigation for the effect. Thus, I am returning the unmodified, signed MOA with one caveat; that you submit one archival quality copy of the HAER documentation to this office and one to a local historical society in the vicinity of Vandenberg Air Force Base. 
USAFOB1009A

2 OF 2

Thank you for your consideration of historic properties as part of your project planning. Please be advised that under certain circumstances, such as unanticipated discovery or a change in project description, the Aif Force may have additional future responsibillties for this undertaking under 36 CFR Part 800 . If you have any questions or concerns; please contact Cheryl Foster. Curley, Project Review Unit archasologist, at (916) 653.0019 or at ccurley@oarks ca.cov.

\section{Sincerely,}

$$
\text { busex } \hbar \text { Stratton for }
$$

Milford Wayne Donaldson, FAIA

State Historic Preservation Of 